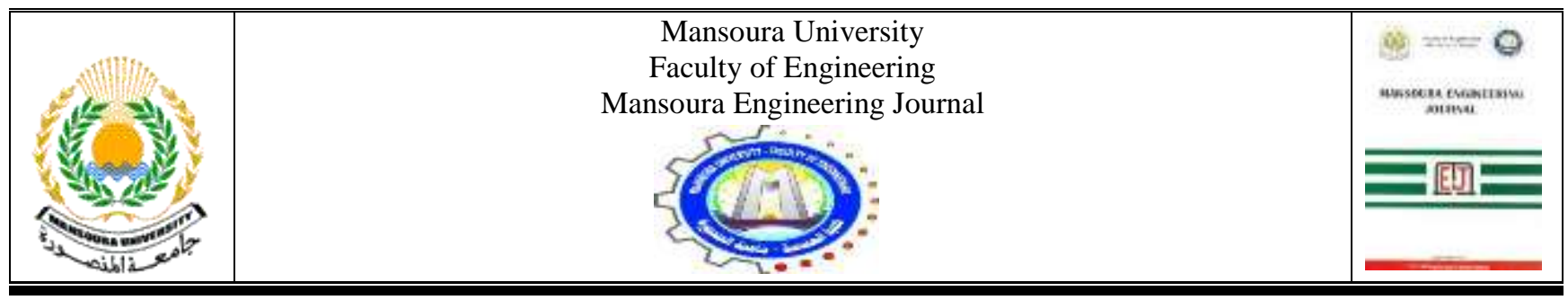

\title{
Proposed Formula for Shear Resistance of Innovative Shear Connector between Cold Formed Steel Section and Concrete

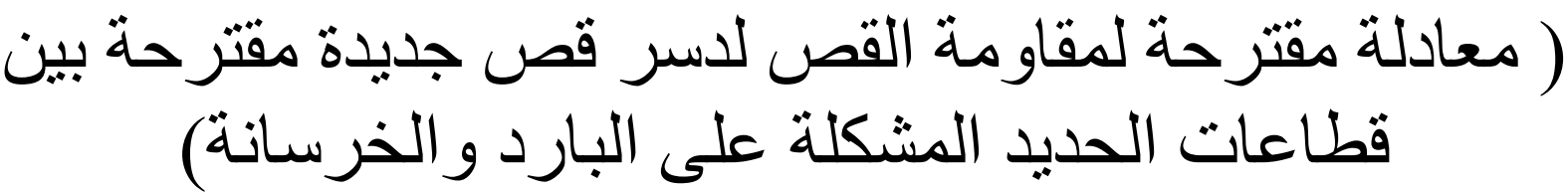

Nabil S. Mahmoud, Saad El-deen M. Abd-rabou, Mohamed ghannam and Ahmed A. Abdel-kader

\begin{abstract}
KEYWORDS:
Cold formed steel; loadslip curves; finite element; push out tests.
\end{abstract}

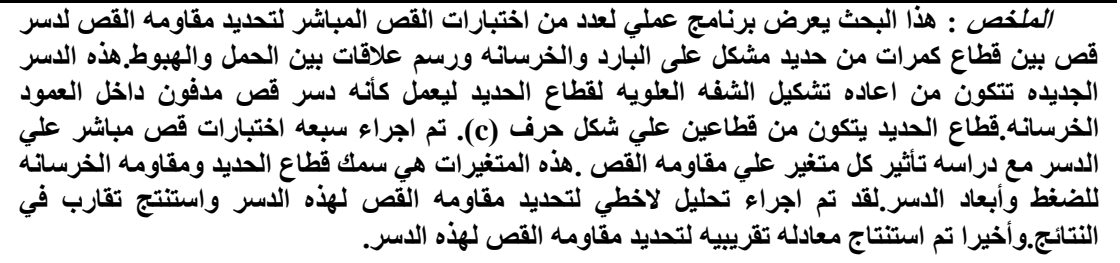



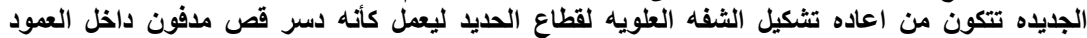

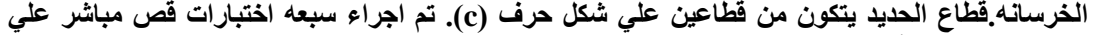

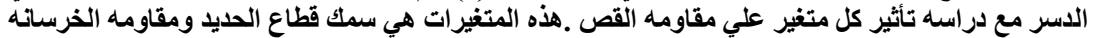
النتائج.وأخيرا تم استنتاج معادله تقريبيه لتحديل مقاومه القيل القص لهذه الاسر.

\begin{abstract}
This paper presents an Experimental investigation for push out tests to determine the shear strength and the loadslip curves of a new shape of the shear connector results from the reforming of the steel cold formed section (CFS). This new shear connector has been used previously in our researches (under publication) to achieve the composite action in composite cold formed steel beams. Seven push out specimens are tested so as to make a parametric study to determine the effect of the variation of different parameters on the strength of the shear connector, the steel section consists of two cold formed steel channel sections back to back of thickness ( $t_{\text {st }}$ ) and $30 \mathrm{~cm}$ height and yield strength ( $\left.f_{y}\right)$ which connected to a reinforced concrete columns $(15 \mathrm{~cm} * 15 \mathrm{~cm})$ of $30 \mathrm{~cm}$ height of compressive strength ( $\left.f_{\mathrm{cu}}\right)$ using means of new shear connector ,the new shear connector is
\end{abstract}

Received: 31 January, 2018 - Accepted: 12 March, 2018

Nabil S. Mahmoud, Prof. of steel structures, Mansoura University, Mansoura, Egypt(nsm_eco@mans.edu.eg)

Saad El-deen M. Abd-rabou, Prof. of steel structures, Mansoura University, Mansoura,Egypt(abdrabou@mans.edu.eg)

Mohamed ghannam, lecturer in structural Engineering Department, Mansoura University, Mansoura, Egypt(m.m.a.ghannam@gmail.com)

Ahmed A. Abdel-kader, Demonstrator in structural Engineering Department, Mansoura University, Mansoura, Egypt(aameed.1991@gmail.com) developed from the reforming of a part of the steel section flange so as to be embedded inside the concrete to resist slippage between steel and concrete.

The studied parameters are the compressive strength of the concrete $\left(f_{c u}\right)$, the yield strength of the steel $\left(f_{y}\right)$, the breadth of the shear connector (b), the height of the shear connector (h) and the thickness of the steel $\left(t_{s t}\right)$

A finite element model has been used to simulate the behavior of the real test so as we will be able to study more parameters with more variations using ABAQUS/CAE, and also an empirical formula can derive to calculate the strength of the suggested shear connectors.

\section{INTRODUCTION}

$\mathrm{F}$ TOR the design of a composite structures using cold formed section (CFS), push out tests should be carried out, in the second half of the 20th century Viest [1] investigated the behavior of the stud connectors. Experiments were carried out on headed stud connectors for the first time with different stud diameters and spacing of the connectors. Also, push-out tests and full-scale beam tests were carried out by Slutter and Driscoll [2], so they derived a relation between the stud resistance and the concrete strength. Driscoll and Slutter [3] found that the ratio between height of 
the connector and diameter $(\mathrm{H} / \mathrm{d} \geq 4)$. Push out tests was executed by Goble [4] with various steel flange thicknesses. It was determined that the shift in failure mode between the connector shear failure and the flange-pull-out failure occurs at a ratio $\left(\mathrm{d} / \mathrm{t}_{\mathrm{f}} \approx 2.7\right)$. A finite element model of push-out tests were developed by Lam and El-Lobody [5]. They compared the numerical results to the experimental results and the design standards - British BS5950 [6], European EC4 [7] and American AISC [8], EC4 [7] gave the best correlation with the experimental and Numerical results, while BS5950 [6] and AISC [8] gave over conservative values.

The advantages of the new shear connector are that they could be fabricated easily in the field and don't require skilled laborers.

The main aim of this research is to derive a simple formula that can predict accurately the strength of the suggested shear connector.

The suggested formula has been verified using the experimental push out tests and using the nonlinear analysis.

\section{EXPERIMENTAL WORK}

This paper is an extension to a previous work on the composite cold formed steel beams using the suggested shear connector. The main aim of this paper is to derive a simple formula to predict the resistance of the shear connector and verified using the experimental work and the nonlinear analysis.

This section highlights the test program undertaken. The test set-up for the tested push out specimens is described. Experimental results and failure modes have been recorded.

The experimental program is composed of seven push out specimens, the push out specimen is composed of CFS beam section connected to concrete columns using the means of the shear connection.

The steel section is composed of two steel channels are connected together using bolts M12 as shown in figure (1) and the used two reinforced concrete columns are of dimensions $(15 \mathrm{~cm} * 15 \mathrm{~cm})$ and reinforced $4 \Phi 12$. They are connected together using the means of the shear connector which results from the reforming of the steel flange to act as a rectangular plate embedded in the concrete of dimensions $\left(b^{*} h\right) \mathrm{cm}$. The standard dimensions are shown in figure (2) to carry out the experiment on the following push out tests the used concrete are of $\mathrm{f}_{\mathrm{cu}}$ of $23 \mathrm{MPA}, 40 \mathrm{MPA}$ and $60 \mathrm{MPA}$, and the used steel grades are steel $37\left(\mathrm{f}_{\mathrm{y}}=2.4 \mathrm{t} / \mathrm{cm}^{2}\right)$ and steel52 $\left(\mathrm{f}_{\mathrm{y}}=3.6\right.$ $\mathrm{t} / \mathrm{cm}^{2}$ ). The used steel thicknesses are $\mathrm{t}_{\mathrm{st}}=2 \mathrm{~mm}$ and $4 \mathrm{~mm}$, the used shear connectors are of breadth $\mathrm{b}=2 \mathrm{~cm}$ and $5 \mathrm{~cm}$ and the used shear connectors are of height $\mathrm{h}=3 \mathrm{~cm}$ and $5 \mathrm{~cm}$ also to prevent the local buckling of the steel web a plain concrete has been casted around the web.
All the tested specimens are shown in the table (I), where po. 1 indicates the push out specimen number. 1 and so on.

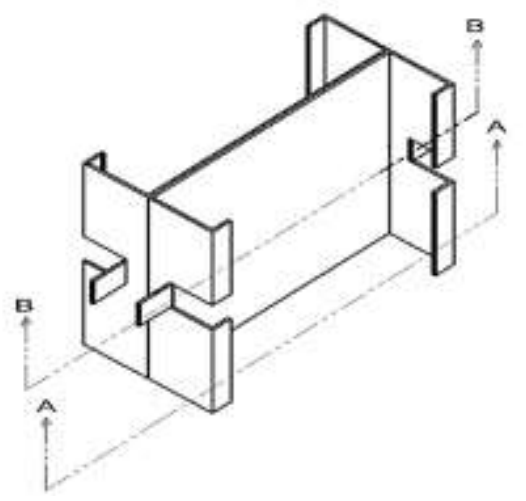

(a): Isometric view of the steel section

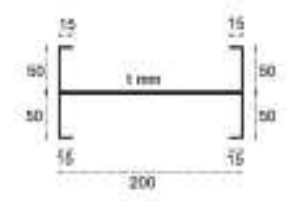

(b): $\operatorname{section}(\mathrm{A}-\mathrm{A})$

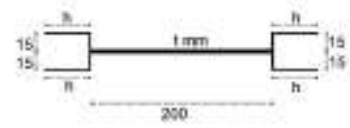

(c): $\operatorname{section}(\mathrm{B}-\mathrm{B})$
Fig. 1.Details of the steel section and the reforming details to act as shear connector

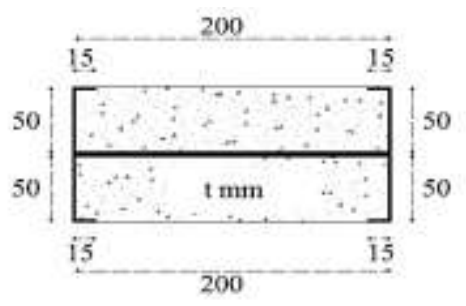

(a): Cross-section of the steel section encased with concrete to prevent local buckling

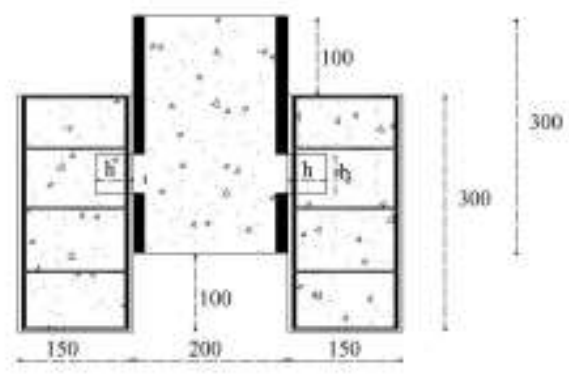

(b): Elevation of the push out test.

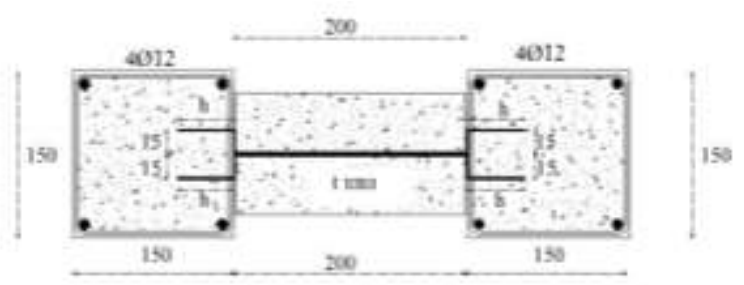

(c):plan view of the push out test

Fig .2. Dimensions and details of the push-out specimen 
TABLE I

\begin{tabular}{|c|c|c|c|c|c|c|}
\hline \multirow{3}{*}{$\begin{array}{c}\text { Studied } \\
\text { parameter }\end{array}$} & \multicolumn{5}{|c|}{ THE DETAILS OF THE TESTED PUSH OUT SPECIMENS } & \\
\hline & specimens & fcu (MPA) & fy $(t / c m 2)$ & Connect & limensions & \\
\hline & & & & tst (mm) & b (cm) & $\mathbf{h}(\mathbf{c m})$ \\
\hline \multirow{3}{*}{$f c u$} & Po.1 & 23 & $2.4 \mathrm{t} / \mathrm{cm} 2$ & $3 \mathrm{~mm}$ & $6.5 \mathrm{~cm}$ & $5 \mathrm{~cm}$ \\
\hline & Po.2 & 41 & $2.4 \mathrm{t} / \mathrm{cm} 2$ & $3 \mathrm{~mm}$ & $6.5 \mathrm{~cm}$ & $5 \mathrm{~cm}$ \\
\hline & Po.3 & 59 & $2.4 \mathrm{t} / \mathrm{cm} 2$ & $3 \mathrm{~mm}$ & $6.5 \mathrm{~cm}$ & $5 \mathrm{~cm}$ \\
\hline \multirow[t]{2}{*}{$f y$} & Po.1 & 23 & $2.4 \mathrm{t} / \mathrm{cm} 2$ & $3 \mathrm{~mm}$ & $6.5 \mathrm{~cm}$ & $5 \mathrm{~cm}$ \\
\hline & Po.4 & 23 & $3.6 \mathrm{t} / \mathrm{cm} 2$ & $3 \mathrm{~mm}$ & $6.5 \mathrm{~cm}$ & $5 \mathrm{~cm}$ \\
\hline \multirow[t]{2}{*}{ tst (mm) } & Po.1 & 23 & $2.4 \mathrm{t} / \mathrm{cm} 2$ & $3 \mathrm{~mm}$ & $6.5 \mathrm{~cm}$ & $5 \mathrm{~cm}$ \\
\hline & Po.5 & 23 & $2.4 \mathrm{t} / \mathrm{cm} 2$ & $4 \mathrm{~mm}$ & $6.5 \mathrm{~cm}$ & $5 \mathrm{~cm}$ \\
\hline \multirow[t]{2}{*}{$h(\mathrm{~cm})$} & Po.1 & 23 & $2.4 \mathrm{t} / \mathrm{cm} 2$ & $3 \mathrm{~mm}$ & $6.5 \mathrm{~cm}$ & $5 \mathrm{~cm}$ \\
\hline & Po.6 & 23 & $2.4 \mathrm{t} / \mathrm{cm} 2$ & $3 \mathrm{~mm}$ & $6.5 \mathrm{~cm}$ & $3 \mathrm{~cm}$ \\
\hline \multirow[t]{2}{*}{$b(\mathrm{~cm})$} & Po.1 & 23 & $2.4 \mathrm{t} / \mathrm{cm} 2$ & $3 \mathrm{~mm}$ & $6.5 \mathrm{~cm}$ & $5 \mathrm{~cm}$ \\
\hline & Po.7 & 23 & $2.4 \mathrm{t} / \mathrm{cm} 2$ & $3 \mathrm{~mm}$ & $2 \mathrm{~cm}$ & $5 \mathrm{~cm}$ \\
\hline
\end{tabular}

\section{MATERIAL PROPERTIES}

\section{A. Reinforced steel}

Three steel tensile coupon tests were carried out to determine the stress-strain curve of the steel plate. The dimensions of the specimen are shown in figure (3). These properties include the average yield stress, ultimate tensile stress and Young's modulus of elasticity of the steel sections and longitudinal reinforcing bars used are listed in Table (II).

The dimensions of the tensile coupon specimens were taken as (ESS) as:

Where:

$$
L_{O}=11.3 \sqrt{A_{O}}
$$

$L_{O}=$ the length of the specimen in $\mathrm{mm}$

$A_{O}=\mathrm{b} * \mathrm{t}$

$\mathrm{t}=$ thickness of the steel plate in $\mathrm{mm}$

$\mathrm{b}=$ width of the specimen in $\mathrm{mm}$

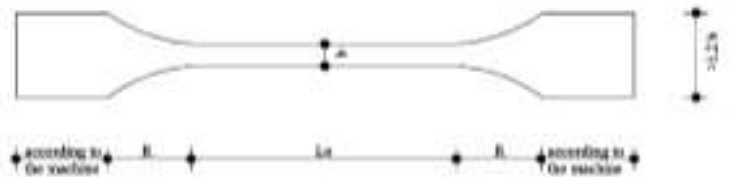

Fig.3. Standard dimensions used in the tensile coupon test

TABLE II

MECHANICAL PROPERTIES OF THE STEEL AND REINFORCING STEEL

\begin{tabular}{l||l||l||l} 
Type & $\mathbf{f y}(\mathbf{t} / \mathbf{c m} \mathbf{2})$ & $\mathbf{f u}(\mathbf{t} / \mathbf{c m} \mathbf{2})$ & $\mathbf{E}(\mathbf{t} / \mathbf{c m} 2)$ \\
\hline Steel section37 & 2.35 & 2.90 & 2060 \\
\hline Steel section 52 & 3.60 & 5.20 & 2100 \\
\hline Reinforcing bar & 3.60 & 4.60 & 2010
\end{tabular}

\section{B. Concrete}

The used concrete mixes are shown in table (III)

TABLE III

THE USED CONCRETE MIXES USED IN THE EXPERIMENTS

\begin{tabular}{c||c||c||c} 
component & $\mathbf{f}_{\mathrm{cu}=\mathbf{0 . 2 3 ~ t} / \mathbf{c m}^{2}}$ & $\mathbf{f}_{\mathrm{cu}=\mathbf{0 . 4 1} \mathbf{~ t / c m 2}}$ & $\mathbf{f}_{\mathrm{cu}=\mathbf{0 . 5 9} \mathbf{~ t} \mathbf{c m}^{\mathbf{2}}}$ \\
\hline Cement & $300 \mathrm{~kg}$ & $500 \mathrm{~kg}$ & $500 \mathrm{~kg}$ \\
\hline Gravel & $1200 \mathrm{~kg}$ & $1074 \mathrm{~kg}$ & $1142 \mathrm{~kg}$ \\
\hline Sand & $800 \mathrm{~kg}$ & $576 \mathrm{~kg}$ & $620 \mathrm{~kg}$ \\
\hline Water & $150 \mathrm{~kg}$ & $215 \mathrm{~kg}$ & $150 \mathrm{~kg}$ \\
\hline $\begin{array}{c}\text { Super } \\
\text { plasticizers }\end{array}$ & ----- & ---- & $20 \mathrm{~kg}$
\end{tabular}

\section{Test Set-up}

The push out specimens was rested on the test bed, one concentrated load at top of the steel section as shown in Figure (4). The applied loads in all tests were carried out using calibrated hydraulic jack connected with an electric hydraulic pump. The capacity of hydraulic jack is 200 tons. For each test, the vertical slip $(\mathrm{mm})$ has been recorded using dial gauges of $0.01 \mathrm{~mm}$ accuracy. During the testing operation, the tested load is applied on the specimen in a constant incremental rate each 10 minutes. During the loading, the outer specimen surface was carefully investigated and the propagation of cracks was followed and marked. The system was secured from all sides before starting the experiment. 


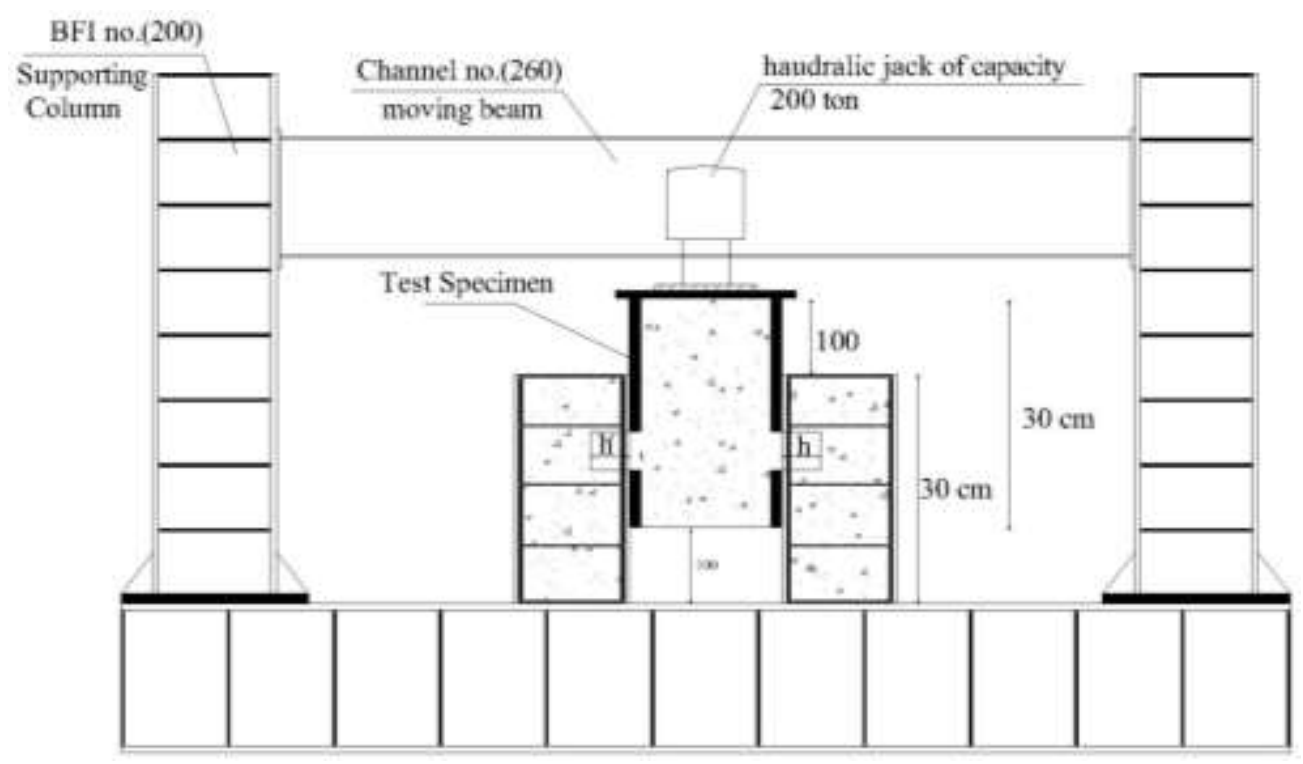

Fig.4. Test setup to experiment the push out specimen

\section{EXPERIMENTAL RESULTS}

The experimental results include the failure loads $\left(\mathrm{P}_{\text {test }}\right)$, the vertical slip $\left(\delta_{\text {test }}\right)$ and their associated failure modes for each tested specimen are discussed in details in this section, where $p_{\text {test }}$ is the ultimate load which causes the failure of two shear connectors on both sides of the steel section ( $\mathrm{p}_{\text {test }}$ is twice the resistance of one shear connector) and $\delta_{\text {test }}$ is the maximum slippage occurs between the steel and concrete before the plastic flow.

\section{A. Recorded Load ( $\left.P_{\text {test }}\right)$}

The relationship between the applied load and the recorded vertical slip for all tested specimens has been investigated as shown in Fig (6). It is noticed from the investigation of the results that the ultimate load $p_{\text {test }}$ increases $23.5 \%$ with the increasing of $\mathrm{f}_{\text {cu }}$ from $23 \mathrm{MPa}$ to $41 \mathrm{MPa}$ and increases 48.82 $\%$ with the increasing of $\mathrm{f}_{\mathrm{cu}}$ from $23 \mathrm{MPa}$ to $59 \mathrm{MPa}$. Also, it is found that the ultimate load $p_{\text {test }}$ increases slightly $(5.8 \%)$ with the increasing of the yield stress of the steel $f_{y}$ equal 2.4 $\mathrm{t} / \mathrm{cm}^{2}$ (steel37) to $\mathrm{f}_{\mathrm{y}}$ equal $3.6 \mathrm{t} / \mathrm{cm}^{2}$ (steel52). Also, it is observed that the ultimate load $p_{\text {test }}$ increases $17.6 \%$ with the increasing of $t_{\text {st }}$ equal $3 \mathrm{~mm}$ to $t_{\text {st }}$ equal $4 \mathrm{~mm}$. Also, it is noticed that the ultimate load $\mathrm{p}_{\text {test }}$ decreases $50 \%$ with the decreasing of the breadth of the connector b equal $6.5 \mathrm{~cm}$ to be equal $2 \mathrm{~cm}$ and it is found that the height of the shear connector is also effective on the ultimate load $p_{\text {test }}$, the value of $p_{\text {test }}$ have been noticed that it decreases $14.6 \%$ due to the decreasing of the height h equal $5 \mathrm{~cm}$ to h equal $3 \mathrm{~cm}$.

\section{B. Maximum vertical slip $\left(\delta_{\text {test }}\right)$}

The relationship between the applied load and the recorded vertical slip for all tested specimens has been investigated as shown in Fig (5). It is noticed from the investigation of the results that the vertical slip $\delta_{\text {test }}$ decreases $31.72 \%$ with the increasing of $\mathrm{f}_{\mathrm{cu}}$ from $23 \mathrm{MPa}$ to $41 \mathrm{MPa}$ and decreases 37.1 $\%$ with the increasing of $\mathrm{f}_{\mathrm{cu}}$ from $23 \mathrm{MPa}$ to $59 \mathrm{MPa}$. Also, it is found that the vertical slip $\delta_{\text {test }}$ decreases slightly (1.344\%) with the increasing of the yield stress of the steel $f_{y}$ equal 2.4 $\mathrm{t} / \mathrm{cm} 2$ (steel37) to $\mathrm{f}_{\mathrm{y}}$ equal $3.6 \mathrm{t} / \mathrm{cm}^{2}$ (steel52). Also, it is observed that the vertical slip $\delta_{\text {test }}$ increases $35.35 \%$ with the increasing of $t_{\mathrm{st}}$ equal $3 \mathrm{~mm}$ to $\mathrm{t}_{\mathrm{st}}$ equal $4 \mathrm{~mm}$. Also, it is noticed that the vertical slip $\delta_{\text {test }}$ decreases $53.63 \%$ with the decreasing of the breadth of the connector b equal $6.5 \mathrm{~cm}$ to $\mathrm{b}$ equal $2 \mathrm{~cm}$ and it is found that the height of the shear connector is also effective on the vertical slip $\delta_{\text {test }}$, the value of $\delta_{\text {test }}$ have been noticed that it decreases $38.91 \%$ due to the decreasing of the height h equal $5 \mathrm{~cm}$ to h equal $3 \mathrm{~cm}$

\section{Failure Modes}

For all the specimens, the failure mode of the suggested shear connector appears in a form of concrete failure and this mode of failure have been observed in po.1, po.2, po.3, po.4, po.5 and po.6 as shown in fig (5.b) and also another failure mode has been noticed, it was appeared in a form of shear cutting in the rectangular steel plate that embedded inside the concrete because the area of the steel web of the shear connector is very small, this mode of failure in po.7 as shown in fig (5.a) 


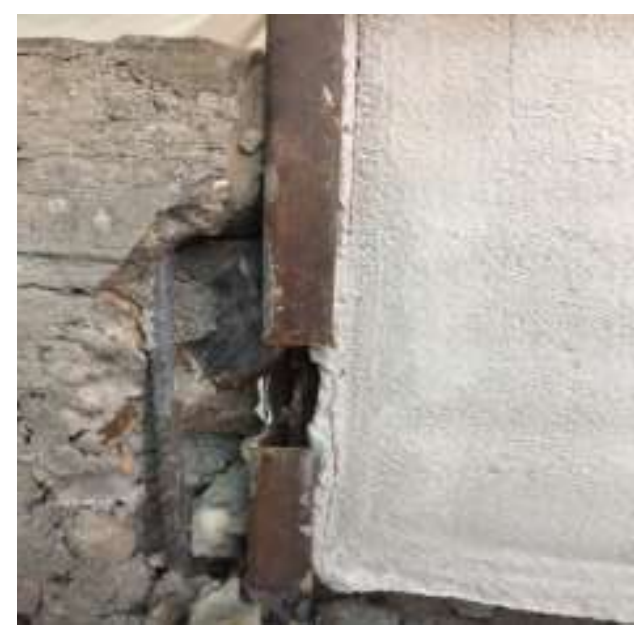

(a): the cutting of the steel failure mode as appeared typically in and po.7



(b): the concrete failure mode as appeared on po.1, po.2, po.3, po. 4 , po. 5 po. 6

Fig .5.Failure modes of the experimented push out specimens
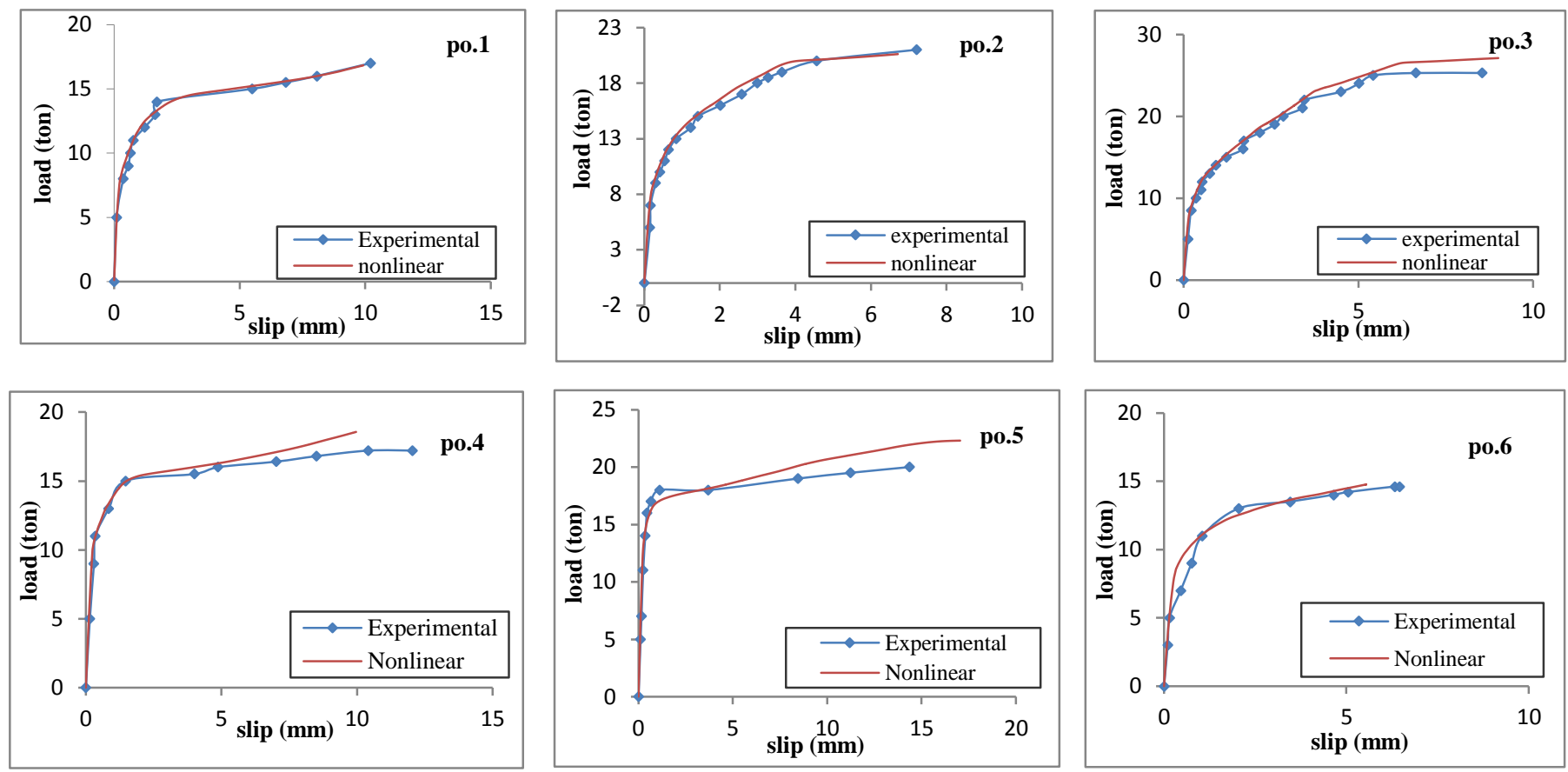

Fig.6. load-slip relation for the tested specimens and the corresponding nonlinear analysis (Continued)

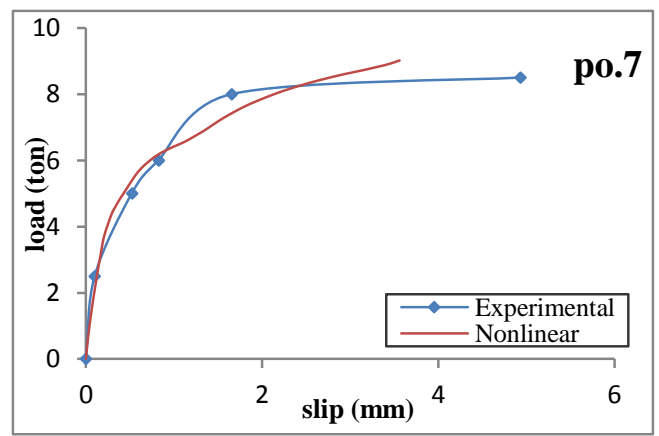

Fig.6. load-slip relation for the tested specimens and the corresponding nonlinear analysis 

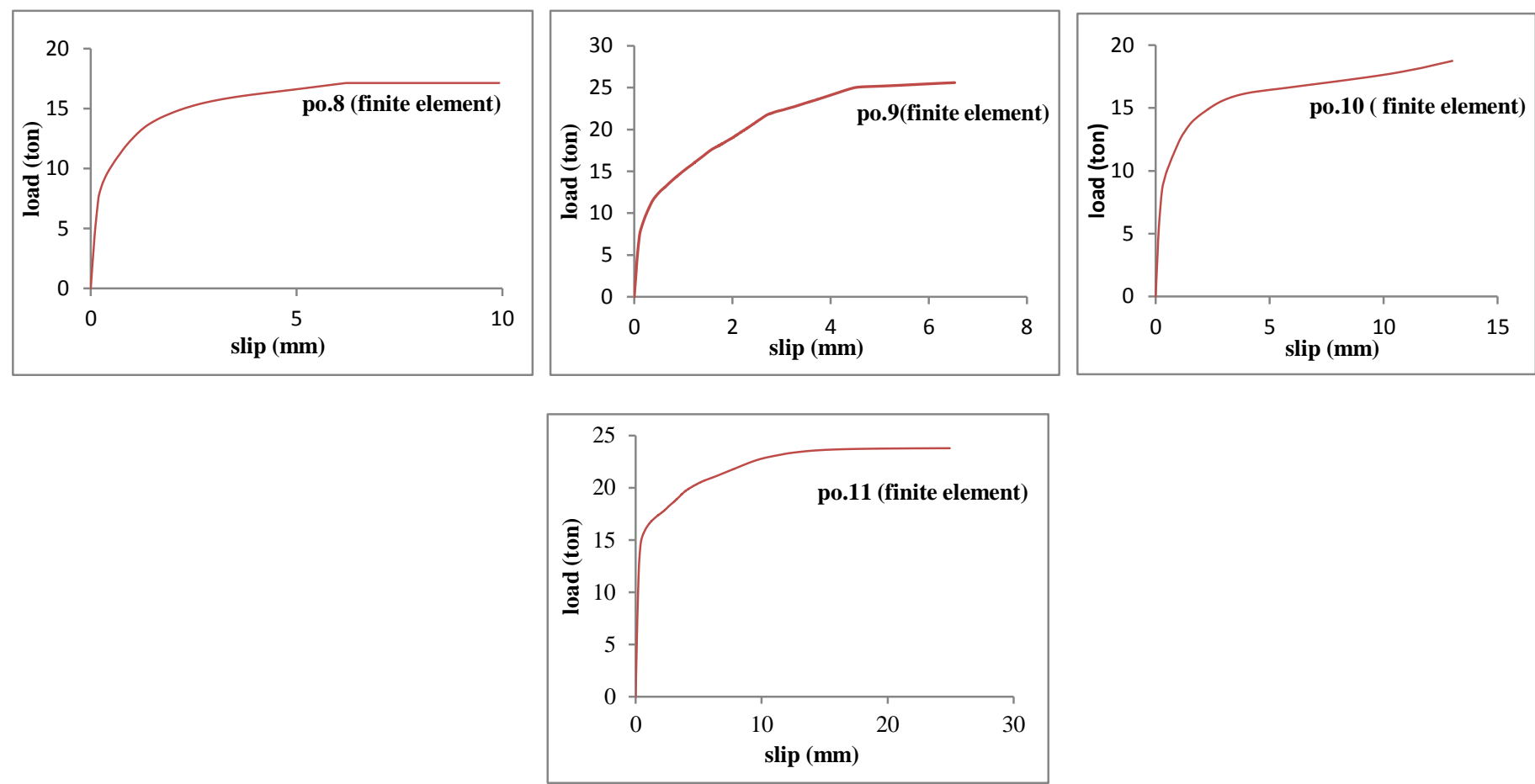

Fig.7.Load-slip relation of the specimen investigated using finite element only

\section{Finite Element Modeling}

This section shows the details of the finite element modeling using ABAQUS/CAE [9] to simulate the behavior of areal push out test.

\section{A. Element types}

The push out specimen components are modeled using a combination of 3-D solid element (C3D8) for concrete, longitudinal bars, and steel section, available in ABAQUS/CAE element library [9], as shown in fig (9). The partition of the model is made to be suitable for the other elements; a mesh $50 \mathrm{~mm}$ depth in can achieve accurate results with average aspect ratio equals 1.2.

\section{B. Boundary conditions}

To give reliable simulation of the beams on the FE, the end of the concrete column was presented in the finite element modeling as fixed support $(\mathrm{U} 1=\mathrm{U} 2=\mathrm{U} 3=\mathrm{UR} 1=\mathrm{UR} 2=\mathrm{UR} 3=0)$ such that preventing the rotation of the specimen around their axis and also preventing the displacement in any direction. And the other end of the specimen is free; the applied load is at the center of gravity of the cross section. To avoid stress concentration at this point, this point is connected with steel beam upper surface using COUPLING option available in the ABAQUS/CAE; the analysis type used is the static general analysis including the nonlinear geometric effect.

\section{Material properties}

Since no tests were made to estimate Young modulus and Poisson ratio, $\mathrm{E}_{\mathrm{c}}=29500 \mathrm{MPa}$ (for concrete of $\mathrm{F}_{\mathrm{cu}}=23 \mathrm{MPa}$ ), $\mathrm{E}_{\mathrm{c}}=320000 \mathrm{MPa}$ (for concrete of $\mathrm{F}_{\mathrm{cu}}=41 \mathrm{MPa}$ ) and $\mathrm{E}_{\mathrm{c}}=$
$390000 \mathrm{MPa}$ (for concrete of $\mathrm{F}_{\mathrm{cu}}=59 \mathrm{MPa}$ ) and $v=0.2$ value were used for them as recommended by the Euro code part $2[10]$ which gives reliable answers, the tensile softening response was characterized by means of fracture energy $\left(\mathrm{G}_{\mathrm{F}}\right)$

$$
G_{F}=\left(0.0469 d_{\max }^{2}-0.5 d_{\max }+26\right)\left(\frac{f_{c}^{\prime}}{10}\right)^{0.7} \mathrm{~N} / \mathrm{m}
$$

Where $f_{c}{ }^{\prime}$ is in MPA, $d_{\max }$ is the maximum coarse aggregate size (in $\mathrm{mm}$ ), if $\mathrm{d}_{\max }$ had not been reported in a reference, it was taken as $20 \mathrm{~mm}$.

The dilation angle, biaxial stress ratio and the tensile-tocompressive meridian ratio were assumed to be equal to 30 , 1.16 , and 0.667 , respectively While for steel and longitudinal bars, $\mathrm{E}_{\mathrm{s}}=210 \mathrm{GPa}$ and $v=0.3$ value have been used respectively as recommended by Euro codepart3 [11], This stress- strain curves achieves the General Method recommended by Euro-code part 2[10] and Euro code part 3 [11] as shown in fig (8)
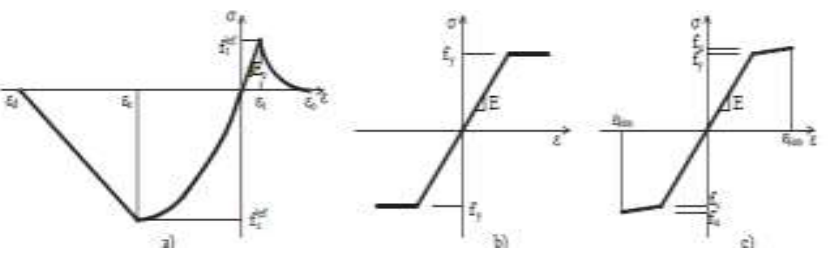

Fig (8): Stress strain curve for a) concrete, b) steel, c) reinforced bars

\section{Interaction between steel and concrete}

The interaction between the steel and concrete was defined as contact with a tangential behavior (friction formulation: 
penalty) with coefficient of friction $=0.6$, and hard contact has been used to simulate the normal behavior.

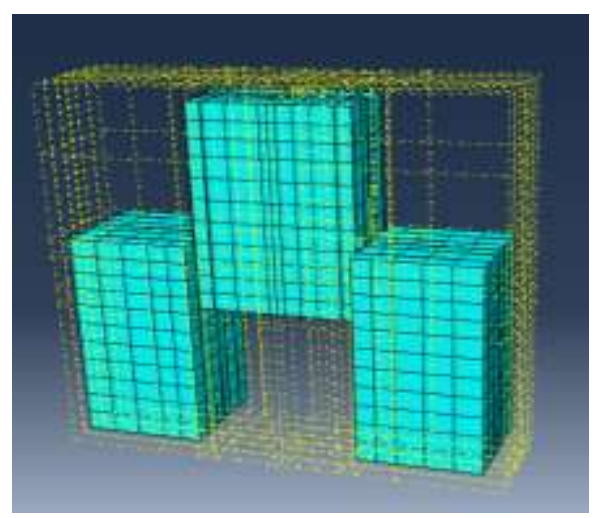

Fig. 9. Meshes of the steel section and the concrete of $50 \mathrm{~mm}$ size

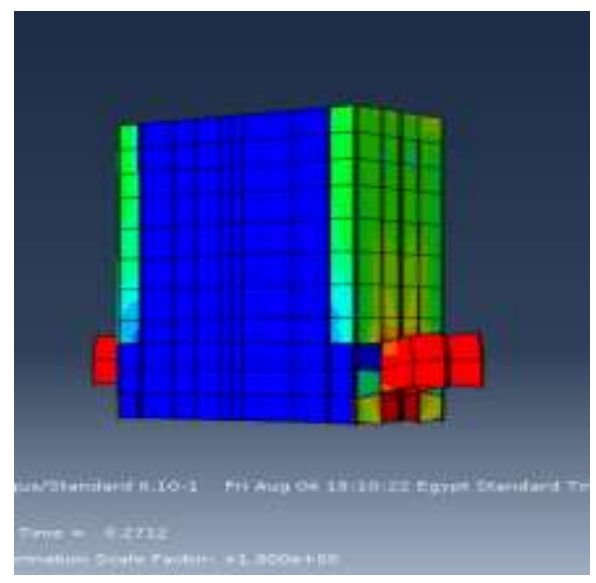

Fig .10 the stress distribution on the shear connector used in po.3

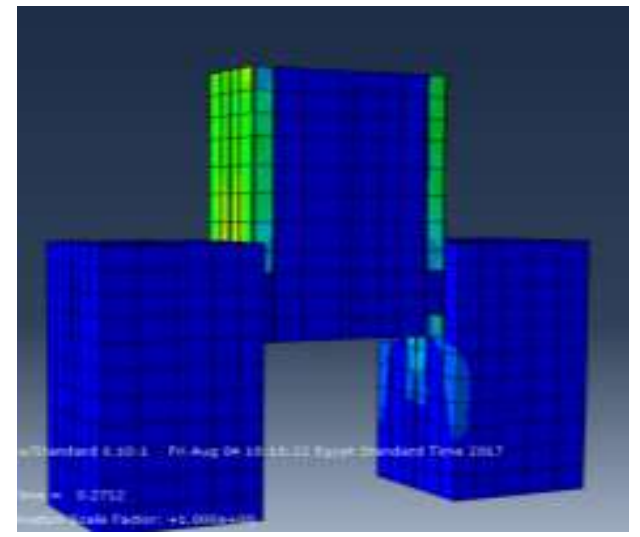

Fig.11.Stress distribution on the whole model used in po.3

\section{FINITE ELEMENT RESULTS}

\section{A. The ultimate load $\left(P_{F E}\right)$}

Using the finite element model, we can determine the shear strength and the load-slip curve for each specimen, the stress distribution on the steel beam and on the whole model as shown in fig (10) and fig (11) and the FE results give a good agreement with the test results from the experimental work, also the failure modes give a great agreement with the real experimental failure mode as shown in fig (12). It is noticed from the investigation of the results that the ultimate load $\mathrm{p}_{\mathrm{FE}}$ increases $22.5 \%$ with the increasing of $\mathrm{f}_{\mathrm{cu}}$ from $23 \mathrm{MPa}$ to 41 $\mathrm{MPa}$ and increases $52.09 \%$ with the increasing of the $\mathrm{f}_{\mathrm{cu}}$ from $23 \mathrm{MPa}$ to $50 \mathrm{MPa}$ and increases $61.045 \%$ with the increasing of $\mathrm{f}_{\mathrm{cu}}$ from $23 \mathrm{MPa}$ to $59 \mathrm{MPa}$. Also, it is found that the ultimate load $\mathrm{p}_{\mathrm{FE}}$ increases slightly $(10.15 \%)$ with the increasing of the yield stress of the steel $f_{y}$ equal $2.4 \mathrm{t} / \mathrm{cm}^{2}$ (steel37) to $\mathrm{f}_{\mathrm{y}}$ equal $3.6 \mathrm{t} / \mathrm{cm}^{2}$ (steel52) and the ultimate load PFE increases $1.75 \%$ with the increasing of the yield stress $f_{y}$ equal $2.4 \mathrm{t} / \mathrm{cm}^{2}$ (steel37) to the yield stress equal $2.8 \mathrm{t} / \mathrm{cm}^{2}$ (steel 44). Also, it is observed that the ultimate load $\mathrm{p}_{\mathrm{FE}}$ increases $32.48 \%$ with the increasing of $t_{s t}$ equal $3 \mathrm{~mm}$ to $t_{s t}$ equal $4 \mathrm{~mm}$ and increases $41.22 \%$ with the increasing of the thickness of the steel from $3 \mathrm{~mm}$ to $6 \mathrm{~mm}$.Also, it is noticed that the ultimate load $\mathrm{p}_{\mathrm{FE}}$ decreases $46.419 \%$ with the decreasing of the breadth of the connector $b$ equal $6.5 \mathrm{~cm}$ to $\mathrm{b}$ equal $2 \mathrm{~cm}$, where the failure mode turns from concrete crushing to a steel connector fracture and it is found that the height of the shear connector is also effective on the ultimate load $\mathrm{p}_{\mathrm{FE}}$, the value of $\mathrm{p}_{\mathrm{FE}}$ have been noticed that it decreases $12.35 \%$ due to the decreasing of the height $\mathrm{h}$ equal $5 \mathrm{~cm}$ to $\mathrm{h}$ equal $3 \mathrm{~cm}$ and that the ultimate load $\mathrm{p}_{\mathrm{FE}}$ increases $11.39 \%$ with the increasing of the height of the shear connector from $5 \mathrm{~cm}$ to $6 \mathrm{~cm}$.

\section{B. Maximum vertical slip $\left(\delta_{F E}\right)$}

The relationship between the applied load and the recorded vertical slip for all tested specimens has been investigated as shown in Fig (5). It is noticed from the investigation of the results that the vertical slip $\delta_{\mathrm{FE}}$ decreases $32.96 \%$ with the increasing of $\mathrm{f}_{\mathrm{cu}}$ from $23 \mathrm{MPa}$ to $41 \mathrm{MPa}$ and decreases 34.77 $\%$ with the increasing of $\mathrm{f}_{\mathrm{cu}}$ from $23 \mathrm{MPa}$ to $50 \mathrm{MPa}$ and decreases $35.92 \%$ with the increasing of $\mathrm{f}_{\mathrm{cu}}$ from $23 \mathrm{MPa}$ to $59 \mathrm{MPa}$. Also, it is found that the vertical slip $\delta_{\mathrm{FE}}$ decreases slightly $(0.454 \%)$ with the increasing of the yield stress of the steel $\mathrm{f}_{\mathrm{y}}$ equal $2.4 \mathrm{t} / \mathrm{cm}^{2}$ (steel37) to $\mathrm{f}_{\mathrm{y}}$ equal $3.6 \mathrm{t} / \mathrm{cm}^{2}$ (steel52) and the vertical slip $\delta_{\text {test }}$ decreases slightly $(0.19 \%)$ with the increasing of the yield stress of the steel $f_{y}$ equal $2.4 \mathrm{t} / \mathrm{cm} 2$ (steel37) to $\mathrm{f}_{\mathrm{y}}$ equal $2.8 \mathrm{t} / \mathrm{cm}^{2}$ (steel44). Also, it is observed that the vertical slip $\delta_{\mathrm{FE}}$ increases $70.15 \%$ with the increasing of $t_{s t}$ equal $3 \mathrm{~mm}$ to $t_{\text {st }}$ equal $4 \mathrm{~mm}$ increases $237.4 \%$ when increasing the thickness from $3 \mathrm{~mm}$ to thickness of $6 \mathrm{~mm}$ and. Also, it is noticed that the vertical slip $\delta_{\mathrm{FE}}$ decreases $64.46 \%$ with the decreasing of the breadth of the connector $b$ equal 6.5 $\mathrm{cm}$ to be equal $2 \mathrm{~cm}$ and it is found that the height of the shear connector is also effective on the vertical slip $\delta_{\mathrm{FE}}$, the value of $\delta_{\mathrm{FE}}$ have been noticed that it decreases $44.65 \%$ due to the decreasing of the height h equal $5 \mathrm{~cm}$ to h equal $3 \mathrm{~cm}$ and that the vertical slip $\delta_{\mathrm{FE}}$ increases $87.31 \%$ when increasing the height $\mathrm{h}$ from $5 \mathrm{~cm}$ to $6 \mathrm{~cm}$. 


\section{COMPARISON BETWEEN THE NONLINEAR ANALYSIS AND THE EXPERIMENTAL RESULTS.}

From table (IV) and fig (5), it is obvious that there is a remarkable agreement between the nonlinear analysis results and the experimental results. the mean values of the ratios $\left(\mathrm{P}_{\text {test }} / \mathrm{p}_{\mathrm{FE}}\right)$ and $\left(\delta_{\mathrm{test}} / \delta_{\mathrm{FE}}\right)$ are 0.97269 and 1.0857 respectively. The standard deviation of the ratios $\left(\mathrm{P}_{\text {test }} / \mathrm{p}_{\mathrm{FE}}\right)$ and $\left(\delta_{\mathrm{test}} / \delta_{\mathrm{FE}}\right)$ are $6.59 \%$ and $16.14 \%$ respectively. Fig (12) shows the experimental results versus the nonlinear analysis results. Fig (13) shows the failure mode experimentally versus the nonlinear analysis.

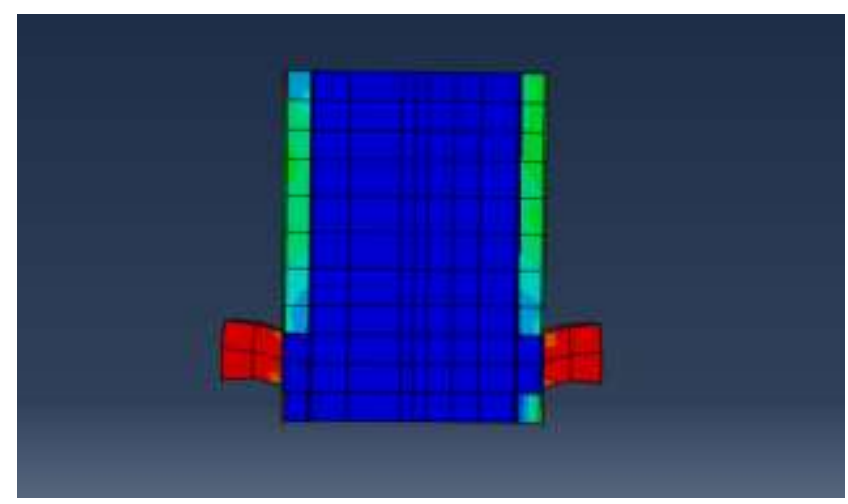

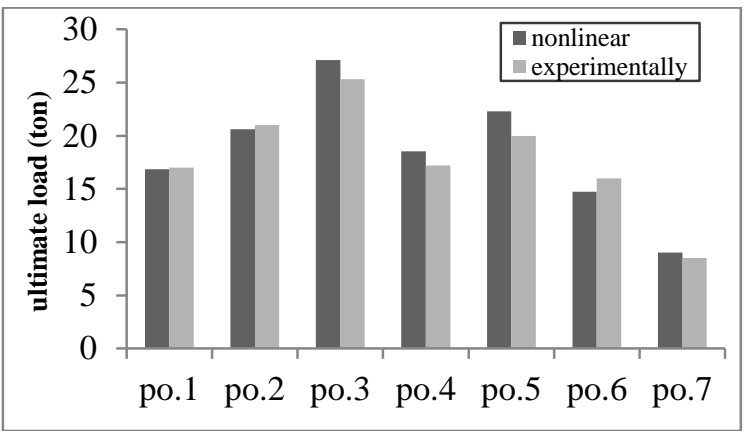

Fig.12. Experimental results versus the nonlinear analysis results

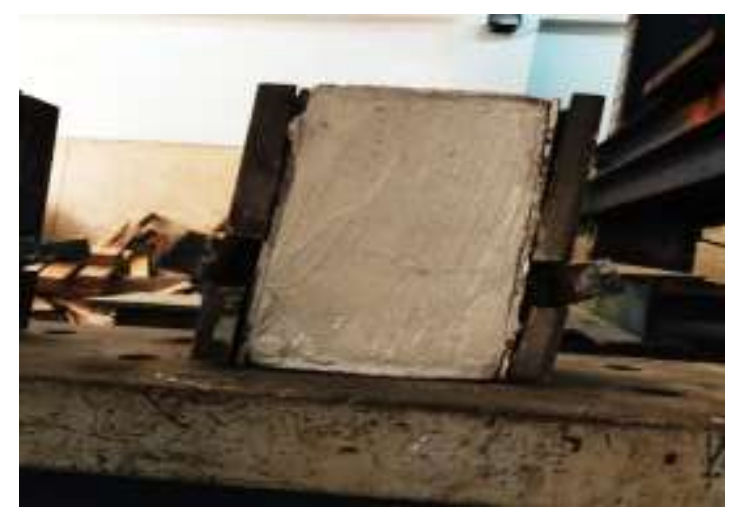

Fig.13. Good agreement between the failure modes between the experimental and nonlinear model

TABLE IV

RESULTS OF THE EXPERIMENTAL PUSH OUT TESTS AND NUMERICAL ANALYSIS AND A COMPARISON BETWEEN THE RESULTS

\begin{tabular}{|c|c|c|c|c|c|c|c|c|c|c|c|}
\hline \multirow[b]{2}{*}{ specimens } & \multicolumn{5}{|c|}{ Studied parameters } & \multicolumn{2}{|c|}{ Exp. results } & \multicolumn{2}{|c|}{ FE results } & \multicolumn{2}{|c|}{ Comparison } \\
\hline & $\mathrm{f}_{\mathrm{cu}}(\mathrm{MPA})$ & $\mathrm{f}_{\mathrm{y}}(\mathrm{t} / \mathrm{cm} 2)$ & $\mathrm{t}_{\mathrm{st}}(\mathrm{mm})$ & $\mathrm{b}(\mathrm{cm})$ & $\mathrm{h}(\mathrm{cm})$ & $\begin{array}{l}\mathrm{p}_{\text {test }} \\
\text { (ton) }\end{array}$ & $\begin{array}{c}\delta_{\text {test }} \\
(\mathrm{mm})\end{array}$ & $\begin{array}{c}\mathrm{P}_{\mathrm{FE}} \\
\text { (ton) }\end{array}$ & $\begin{array}{c}\delta_{\mathrm{FE}} \\
(\mathrm{mm})\end{array}$ & $\mathrm{P}_{\text {test }} / \mathrm{p}_{\mathrm{FE}}$ & $\delta_{\text {test }} / \delta_{\mathrm{FE}}$ \\
\hline Po.1 & 23 & $2.4 \mathrm{t} / \mathrm{cm} 2$ & $3 \mathrm{~mm}$ & $6.5 \mathrm{~cm}$ & $5 \mathrm{~cm}$ & 17 & 10.565 & 16.84 & 10.01 & 1.009 & 1.0656 \\
\hline Po.2 & 41 & $2.4 \mathrm{t} / \mathrm{cm} 2$ & $3 \mathrm{~mm}$ & $6.5 \mathrm{~cm}$ & $5 \mathrm{~cm}$ & 21 & 7.2136 & 20.63 & 6.713 & 1.017 & 1.0745 \\
\hline$P o .3$ & 59 & $2.4 \mathrm{t} / \mathrm{cm} 2$ & $3 \mathrm{~mm}$ & $6.5 \mathrm{~cm}$ & $5 \mathrm{~cm}$ & 25.3 & 6.639 & 27.12 & 6.417 & 0.9328 & 1.0346 \\
\hline Po.4 & 23 & $3.6 \mathrm{t} / \mathrm{cm} 2$ & $3 \mathrm{~mm}$ & $6.5 \mathrm{~cm}$ & $5 \mathrm{~cm}$ & 17.2 & 10.423 & 18.55 & 9.969 & 0.9272 & 1.0455 \\
\hline Po.5 & 23 & $2.4 \mathrm{t} / \mathrm{cm} 2$ & $4 \mathrm{~mm}$ & $6.5 \mathrm{~cm}$ & $5 \mathrm{~cm}$ & 20 & 14.3 & 22.31 & 17.04 & 0.8964 & 0.8392 \\
\hline Po.6 & 23 & $2.4 \mathrm{t} / \mathrm{cm} 2$ & $3 \mathrm{~mm}$ & $6.5 \mathrm{~cm}$ & $3 \mathrm{~cm}$ & 16 & 6.454 & 14.76 & 5.543 & 1.084 & 1.16435 \\
\hline Po.7 & 23 & $2.4 \mathrm{t} / \mathrm{cm} 2$ & $3 \mathrm{~mm}$ & $2 \mathrm{~cm}$ & $5 \mathrm{~cm}$ & 8.5 & 4.9 & 9.023 & 3.559 & 0.942 & 1.3767 \\
\hline \multicolumn{10}{|c|}{ average } & 0.97269 & 1.0857 \\
\hline \multicolumn{10}{|c|}{ Coefficient of variance } & 0.0659 & 0.16144 \\
\hline
\end{tabular}

TABLE V

RESULTS OF THE PUSH OF TESTS THAT INVESTIGATED USING THE FE MODELING ONLY

\begin{tabular}{|c|c|c|c|c|c|c|c|}
\hline specimens & fcu & fy & $\mathbf{h}(\mathbf{c m})$ & $\mathbf{b}(\mathbf{c m})$ & tst & PFE & $\delta F E$ \\
\hline PO.8 & 23 & $2.8 \mathrm{t} / \mathrm{cm} 2$ & $5 \mathrm{~cm}$ & $6.5 \mathrm{~cm}$ & $3 \mathrm{~mm}$ & 17.1363 & 9.9945 \\
\hline PO.9 & 50 & $2.4 \mathrm{t} / \mathrm{cm} 2$ & $5 \mathrm{~cm}$ & $6.5 \mathrm{~cm}$ & $3 \mathrm{~mm}$ & 25.6123 & 6.5321 \\
\hline PO.10 & 23 & $2.4 \mathrm{t} / \mathrm{cm} 2$ & $6 \mathrm{~cm}$ & $6.5 \mathrm{~cm}$ & $3 \mathrm{~mm}$ & 18.7589 & 13.0041 \\
\hline PO.11 & 23 & $2.4 \mathrm{t} / \mathrm{cm} 2$ & $5 \mathrm{~cm}$ & $6.5 \mathrm{~cm}$ & $6 \mathrm{~mm}$ & 23.7817 & 24.9511 \\
\hline
\end{tabular}




\section{PROPOSED FORMULA FOR THE STRENGTH OF THE SUGGESTED SHEAR CONNECTOR}

The main aim of this section is to derive an efficient mathematical model to predict the shear resistance of the proposed shear connector.

\section{A. Failure mechanism of the suggested shear connector:}

As mentioned before in fig (6.a) and (6.b), there are two main possible failure modes for the composite shear connection. The first one is the crushing of the concrete. This type of failure commonly occurs when using a rigid connector with normal or low strength concrete. the second mechanism is the shearing off of the shear connector without severe damage in the concrete $[13,14]$. The possibility of happening of each failure mode depends on both the rigidity of the shear connector and the concrete strength.

For the tested push out specimens using the proposed shear connector, the first failure mode was dominant due to the increasing of the rigidity of the shear connector with respect to the concrete strength as shown in fig (6.b). However, if a lower stiffness connector and higher stiffness concrete was used, the second mechanism could happen as shown in fig (6.a).

Because of the possible two modes of failure, two design formulas are required. The first formula is related to the first mode of failure depending on the bearing resistance of the concrete and the second formula depends on the shearing resistance of the connector. The connector resistance is the minimum value of the both formulas.

\section{B. Shear resistance formula for the proposed shear} connector:

From the analysis of the presented test results, two formulas will be presented in accordance with the possible two modes of failure. After that, the minimum value of both equations will be used to estimate the shear capacity of the shear connector.

\section{B.1 Shear resistance formula (related to the concrete failure):}

The shear strength between the steel and the concrete depends mainly on the bearing resistance of the concrete in front of the connector web (X), that term could be calculated by multiplying the bearing strength of the concrete, which equal $\left(0.67 \mathrm{f}_{\mathrm{cu}}\right)$ according to the ECP [12], by the area of the connector web. Where $\mathrm{X}$ is the bearing resistance of the concrete

So, the shear strength of the shear connector (related to the concrete failure could be expressed as follow:

$$
Q_{1}=\lambda_{1} X+\lambda_{2}
$$

Where $\lambda 1, \lambda 2$ are the factors acquired by the fitting the data obtained experimentally from those specimens that subjected to the concrete failure mode (po.1, po.2, po.3, po.4, po.5 and po.6) as given in table (VI). The result of the specimen po.7 was excluded from the curve fitting on the data because the specimen po.7 is subjected to steel connector failure.

$$
\text { Where } X=0.67 f_{\text {cu }} t_{\text {st }} h
$$

\begin{tabular}{|c|c|c|c|c|c|c|c|c|}
\hline \multirow[b]{2}{*}{ specimens } & \multicolumn{5}{|c|}{ THE VALUES OF THE BEARING RESISTANCE F } & \multicolumn{2}{|c|}{$\begin{array}{l}\text { R THE TESTED PUSH OUT SPECIMENS } \\
\text { Qtest }\end{array}$} & \multirow{2}{*}{$\frac{\mathbf{X}}{\begin{array}{c}\text { Bearing } \\
\text { (ton) }\end{array}}$} \\
\hline & $\begin{array}{c}\text { fcu } \\
(\mathbf{M P A})\end{array}$ & $\begin{array}{c}\mathbf{f y} \\
(\mathbf{t} / \mathrm{cm} 2)\end{array}$ & $\begin{array}{c}\text { tst } \\
(\mathbf{m m})\end{array}$ & $\mathbf{b}(\mathbf{c m})$ & h (cm) & (ton) & & \\
\hline Po.1 & 23 & $2.4 \mathrm{t} / \mathrm{cm} 2$ & $3 \mathrm{~mm}$ & $6.5 \mathrm{~cm}$ & $5 \mathrm{~cm}$ & 4.25 & Concrete crushing & 0.23115 \\
\hline Po.2 & 41 & $2.4 \mathrm{t} / \mathrm{cm} 2$ & $3 \mathrm{~mm}$ & $6.5 \mathrm{~cm}$ & $5 \mathrm{~cm}$ & 5.25 & Concrete crushing & 0.603 \\
\hline Po.3 & 59 & $2.4 \mathrm{t} / \mathrm{cm} 2$ & $3 \mathrm{~mm}$ & $6.5 \mathrm{~cm}$ & $5 \mathrm{~cm}$ & 6.325 & Concrete crushing & 2.412 \\
\hline Po.4 & 23 & $3.6 \mathrm{t} / \mathrm{cm} 2$ & $3 \mathrm{~mm}$ & $6.5 \mathrm{~cm}$ & $5 \mathrm{~cm}$ & 4.3 & Concrete crushing & 0.23115 \\
\hline Po.5 & 23 & $2.4 \mathrm{t} / \mathrm{cm} 2$ & $4 \mathrm{~mm}$ & $6.5 \mathrm{~cm}$ & $5 \mathrm{~cm}$ & 5 & Concrete crushing & 0.3082 \\
\hline Po.6 & 23 & $2.4 \mathrm{t} / \mathrm{cm} 2$ & $3 \mathrm{~mm}$ & $6.5 \mathrm{~cm}$ & $3 \mathrm{~cm}$ & 3.65 & Concrete crushing & 0.13869 \\
\hline Po.7 & 23 & $2.4 \mathrm{t} / \mathrm{cm} 2$ & $3 \mathrm{~mm}$ & $2 \mathrm{~cm}$ & $5 \mathrm{~cm}$ & 2.125 & connector shearing off & 0.09246 \\
\hline
\end{tabular}

Where $\mathrm{Q}_{\text {Test }} /$ connector $=\mathrm{P}_{\mathrm{TEST}} / 4$ (because of the presence of two shear connector in the two sides of the steel beam).

Fig (14) shows the relation between the shear resistances of the shear connector obtained experimentally versus the concrete bearing resistance. Fitting has been applied on the data to obtain an equation in the form of $(y=\lambda 1 x+\lambda 2)$. The values of the constants $(\lambda 1, \lambda 2)$ are 5.6625 and 2.9893 respectively; the coefficient of determination $R^{2}$ between the shear resistance values obtained experimentally and the bearing resistance values $(\mathrm{X})$ is 0.9787 which ensures the efficiency of the statistical model. By applying the values of the constants we get the following expression:

$$
\mathrm{Q}_{1} \text { (ton) }=5.6625 * 0.67 \mathrm{f}_{\text {cu }} \mathrm{t}_{\mathrm{st}} \mathrm{h}+2.9893
$$

And this means that the final formula to predict the shear resistance of the shear connector (related to the concrete crushing):

$$
\mathrm{Q}_{1}(\mathrm{ton})=3.8 \mathrm{f}_{\mathrm{cu}} \mathrm{t}_{\mathrm{st}} \mathrm{h}+3
$$




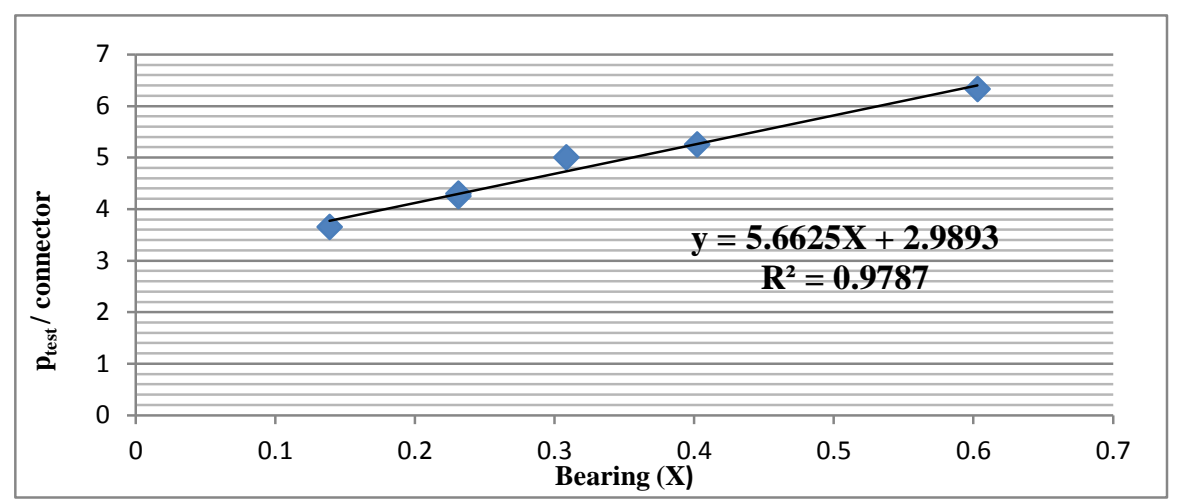

Fig.14. Fitting of the bearing resistance values versus the shear resistance of the shear connector for the tested push out specimens

\section{B.2 Shear resistance formula (related to the connector fracture):}

As illustrated before in the previous section, another mode of failure could occur which is the shearing of the shear connector or the fracture of the shear connector. this mode depends mainly on the area of the cross section of the steel shear connector and on the ultimate stress of the used steel.so, the shear resistance of the shear connector (related to the connector fracture) could be calculated by the following equation:

$$
Q_{2}(\text { ton })=A_{s c} f_{c u}=t_{s t} b f_{u}
$$

Where:

$\mathrm{f}_{\mathrm{cu}}$ : the concrete cubic strength $\left(\mathrm{t} / \mathrm{cm}^{2}\right)$

$f_{u}$ : the ultimate stress of the steel of the shear connector $\left(\mathrm{t} / \mathrm{cm}^{2}\right)$

$\mathrm{A}_{\mathrm{sc}}$ : the area of the connector web $\left(\mathrm{cm}^{2}\right)$

$\mathrm{t}_{\mathrm{st}}$ : the thickness of the steel shear connector $(\mathrm{cm})$

$\mathrm{h}$ : the height of the shear connector $(\mathrm{cm})$

b: the breadth of the shear connector $(\mathrm{cm})$

\section{B.3 Design shears resistance equation of the proposed shear connector:}

From the presented formulas eq (1) and eq (2) that represent the possible two modes of failure of the shear connector. The nominal resistance of the shear connector may be represented by the minimum of the two values as presented in eq (3)

$$
Q_{n}(t o n)=\min \text { of }\left(Q_{1}, Q_{2}\right)
$$

For the design purpose, this nominal strength will be reduced by applying a safety factor $\Phi_{\mathrm{sc}}$ which is equal to 0.8 . therefore, the design ultimate shear resistance of the proposed shear connector could be expressed as seen in eq (4)

$$
Q_{d}(\text { ton })=\Phi_{s c} Q_{n}
$$

Finally, the proposed design shear equation will be verified against the results of the experimental push out tests on the new suggested shear connector.

\section{B.4 Verification of the proposed design equation:}

To ensure the validation of the proposed equation, its results will be verified against the results that obtain from the tested push out specimens. Table (VII) shows the values of the experiments and the nominal strength of the shear connector obtained from the proposed formula as calculated by eq (3). The shear resistance values calculated in the table (7) are based on the properties of the shear connectors and the concrete shown previously in table (I). Furthermore, the validation ratio $\left(\mathrm{Q}_{\text {eqn }} / \mathrm{Q}_{\text {test }}\right)$ will be presented. moreover, fig (15) shows the experimental results versus the predicted values from the equation (3) and fig (16) shows the evaluation of the proposed model. Also, fig (17) shows the shear strength ratios for the tested specimens.

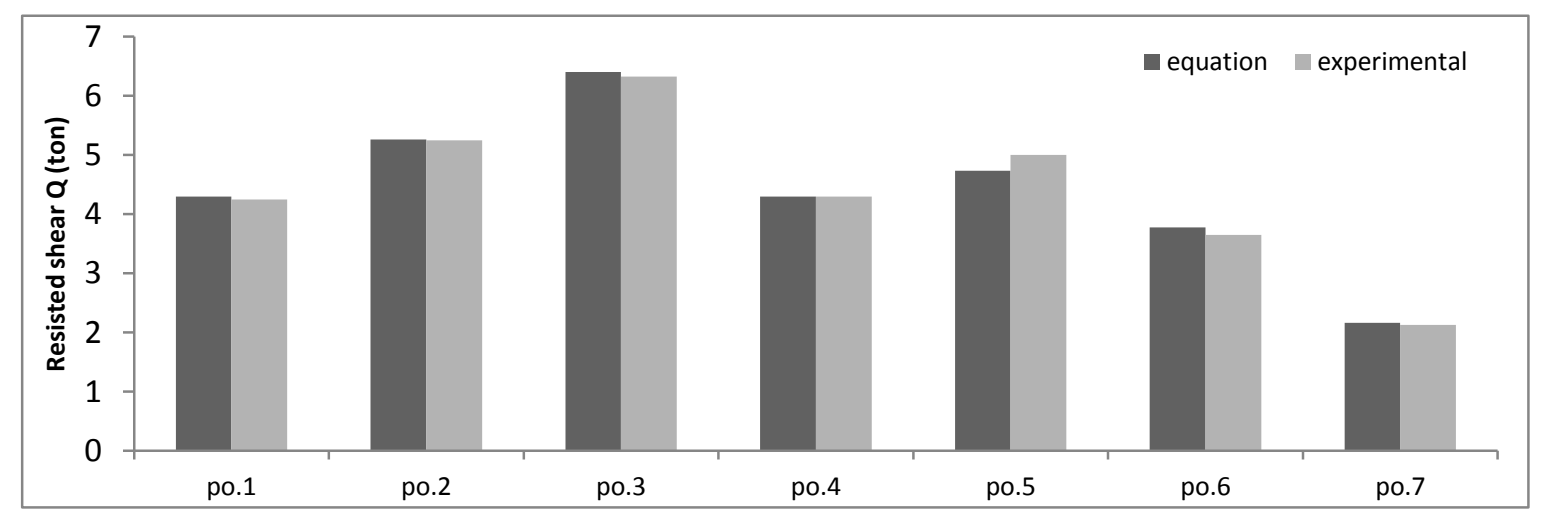

Fig.15. Experimental versus the shear resistance calculated from the proposed equation 
TABLE VII

\begin{tabular}{|c|c|c|c|c|c|c|c|c|c|c|c|}
\hline \multirow[b]{3}{*}{ specimens } & \multicolumn{11}{|c|}{ SHEAR RESISTANCE CALCULATED FROM THE PROPOSED EQUATION VERSUS THE EXPERIMENTAL RESULTS } \\
\hline & \multicolumn{5}{|c|}{ Studied parameters } & \multirow{2}{*}{$\begin{array}{c}\mathbf{Q}_{\text {test }} \\
\text { /connector } \\
\text { (ton) }\end{array}$} & \multicolumn{3}{|c|}{ Qeqn. } & \multirow[b]{2}{*}{ Failure mode } & \multirow[b]{2}{*}{$\mathbf{Q}_{\text {eqn }} / \mathbf{Q}_{\text {TEST }}$} \\
\hline & $\begin{array}{c}\mathbf{f}_{\mathrm{cu}} \\
(\mathrm{MPA})\end{array}$ & $\begin{array}{c}F_{y} \\
(t / c m 2)\end{array}$ & $\begin{array}{c}\mathbf{t}_{\mathrm{st}} \\
(\mathbf{m m})\end{array}$ & $\begin{array}{c}\text { b } \\
(\mathbf{c m})\end{array}$ & $\begin{array}{c}\text { h } \\
(\mathbf{c m})\end{array}$ & & $\mathbf{Q}_{1}$ & $\mathbf{Q}_{2}$ & $\mathbf{Q}_{\mathbf{n}}$ & & \\
\hline Po.1 & 23 & $2.4 \mathrm{t} / \mathrm{cm} 2$ & $3 \mathrm{~mm}$ & $\begin{array}{l}6.5 \\
\mathrm{~cm}\end{array}$ & $5 \mathrm{~cm}$ & 4.25 & 4.298 & 7.02 & 4.298 & Concrete crushing & 1.011 \\
\hline Po.2 & 40 & $2.4 \mathrm{t} / \mathrm{cm} 2$ & $3 \mathrm{~mm}$ & $\begin{array}{l}6.5 \\
\mathrm{~cm}\end{array}$ & $5 \mathrm{~cm}$ & 5.25 & 5.265 & 7.02 & 5.265 & Concrete crushing & 1.002 \\
\hline Po.3 & 60 & $2.4 \mathrm{t} / \mathrm{cm} 2$ & $3 \mathrm{~mm}$ & $\begin{array}{l}6.5 \\
\mathrm{~cm}\end{array}$ & $5 \mathrm{~cm}$ & 6.325 & 6.403 & 7.02 & 6.403 & Concrete crushing & 1.012 \\
\hline Po.4 & 23 & $3.6 \mathrm{t} / \mathrm{cm} 2$ & $3 \mathrm{~mm}$ & $\begin{array}{l}6.5 \\
\mathrm{~cm}\end{array}$ & $5 \mathrm{~cm}$ & 4.3 & 4.298 & 10.14 & 4.298 & Concrete crushing & 0.999 \\
\hline Po.5 & 23 & $2.4 \mathrm{t} / \mathrm{cm} 2$ & $4 \mathrm{~mm}$ & $\begin{array}{l}6.5 \\
\mathrm{~cm}\end{array}$ & $5 \mathrm{~cm}$ & 5 & 4.734 & 7.02 & 4.734 & Concrete crushing & 0.9468 \\
\hline Po.6 & 23 & $2.4 \mathrm{t} / \mathrm{cm} 2$ & $3 \mathrm{~mm}$ & $\begin{array}{l}6.5 \\
\mathrm{~cm}\end{array}$ & $3 \mathrm{~cm}$ & 3.65 & 3.774 & 7.02 & 3.774 & Concrete crushing & 1.033 \\
\hline Po.7 & 23 & $2.4 \mathrm{t} / \mathrm{cm} 2$ & $3 \mathrm{~mm}$ & $2 \mathrm{~cm}$ & $5 \mathrm{~cm}$ & 2.125 & 3.512 & 2.16 & 2.16 & $\begin{array}{l}\text { connector shearing } \\
\text { off }\end{array}$ & 1.016 \\
\hline & & & & & & & & & & Mean & 1.002829 \\
\hline & & & & & & & & & & $\begin{array}{l}\text { Standard } \\
\text { deviation }\end{array}$ & 0.027047 \\
\hline
\end{tabular}

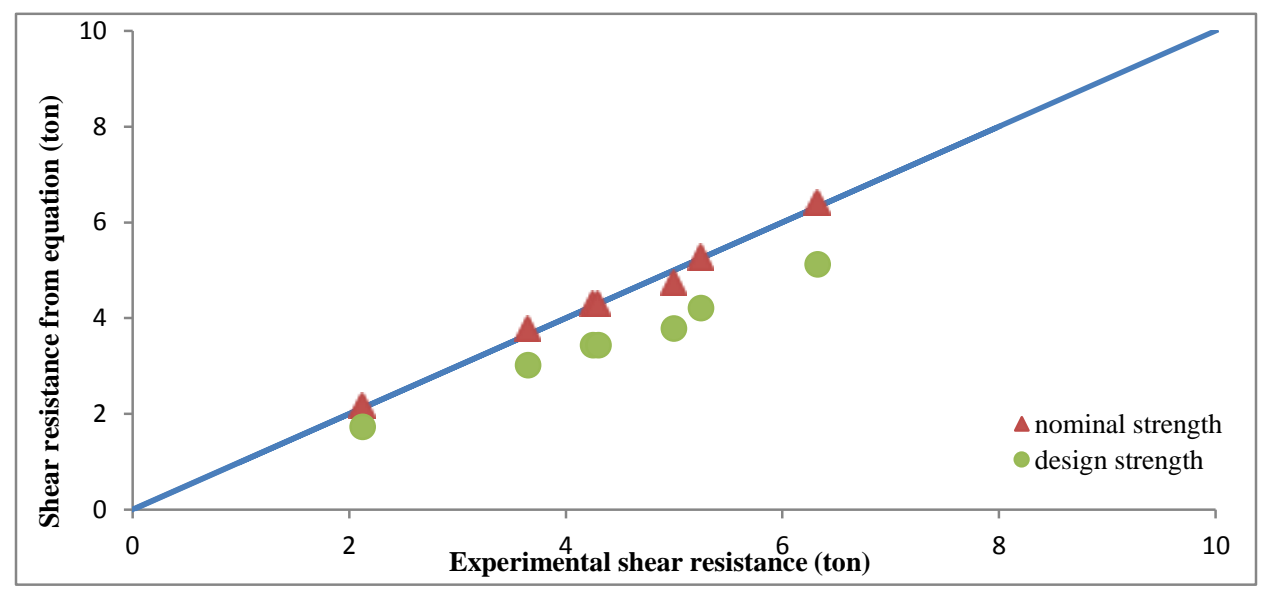

Fig.16. Verification of the proposed equation

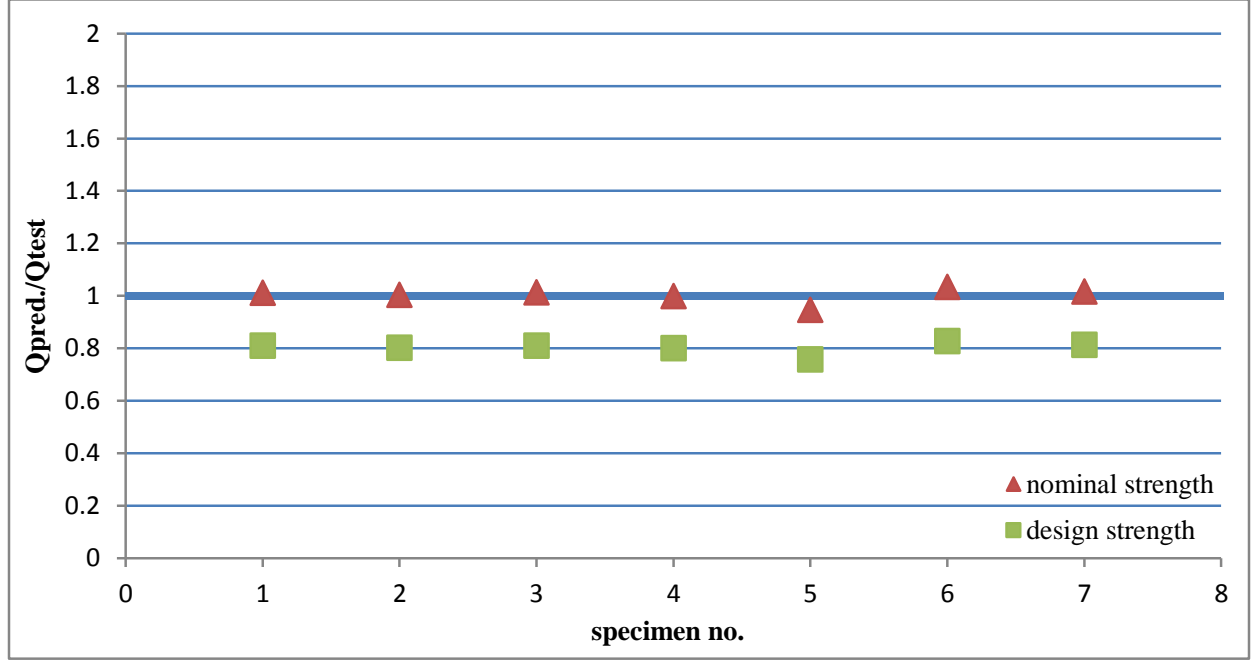

Fig.17. Shear strength ratio for the tested shear connectors 


\section{B.5 Comparison between the nonlinear finite element results and the proposed formula:}

The shear resistance values calculated previously using the finite element analysis based on the properties of the shear connector and the concrete shown in table (I) will be compared with the shear resistance calculated by the proposed formula with the eq (3) as shown in table (8). Fig (18) shows the nonlinear results versus the proposed formula results it is noticed that the mean value of ratios $\left(\mathrm{Q}_{\mathrm{eqn} .} \mathrm{Q}_{\mathrm{FE}}\right)$ is equal to 0.962273 with standard deviation of $5.59 \%$.

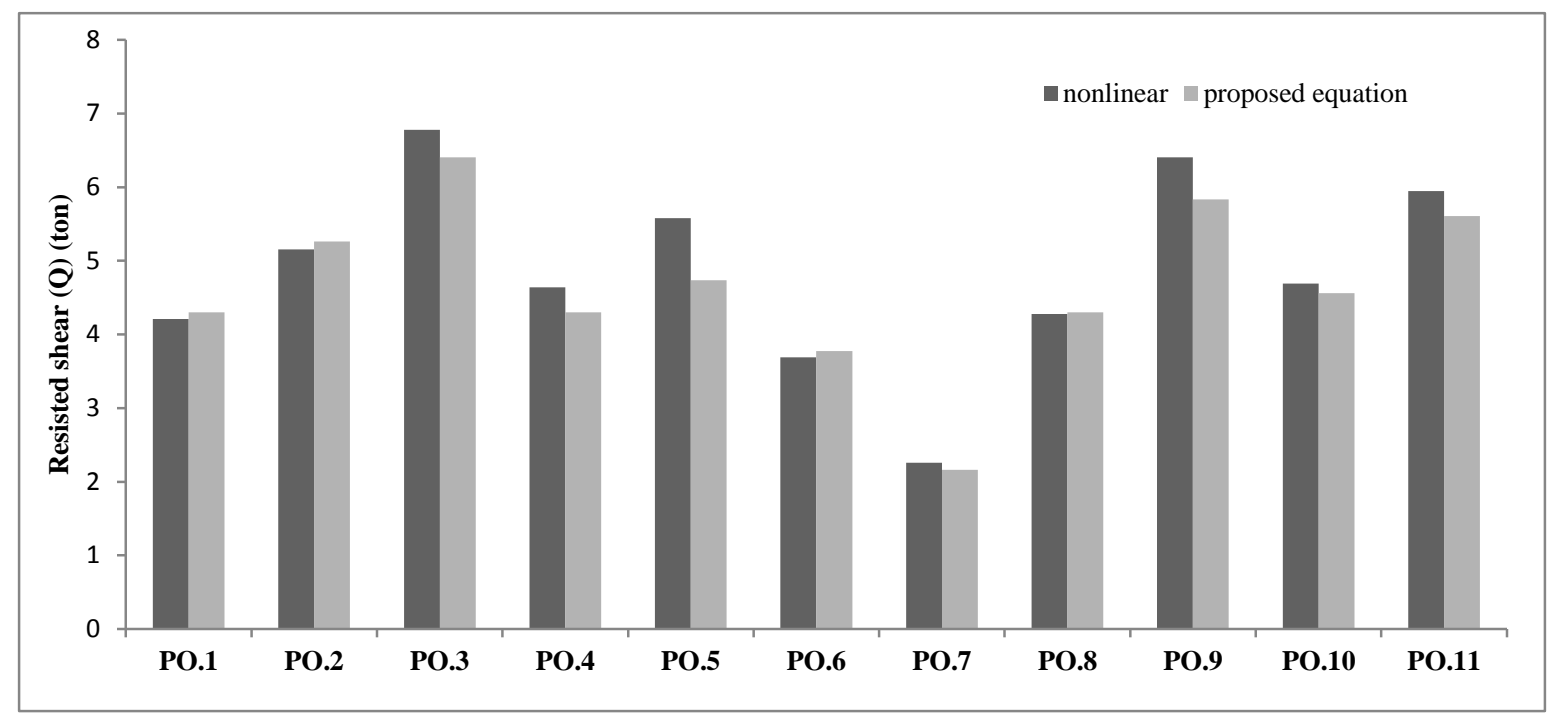

Fig.18. Nonlinear results versus the proposed formula results

TABLE VIII

NONLINEAR RESULTS VERSUS THE PROPOSED FORMULA RESULTS

\begin{tabular}{|c|c|c|c|c|c|c|c|c|c|c|c|}
\hline \multirow{2}{*}{ specimens } & \multicolumn{5}{|c|}{ Studied parameters } & \multirow{2}{*}{$\begin{array}{c}\mathrm{Q}_{\mathrm{FE}} / \\
\text { connector } \\
\text { (ton) }\end{array}$} & \multicolumn{3}{|c|}{$\mathbf{Q}_{\text {eqn. }}$} & \multirow[b]{2}{*}{ Failure mode } & \multirow[b]{2}{*}{$\mathbf{Q}_{\text {eqn }} / \mathbf{Q}_{\mathrm{FE}}$} \\
\hline & $\begin{array}{c}\mathbf{f}_{\mathrm{cu}} \\
(\mathbf{M P A})\end{array}$ & $\begin{array}{c}f_{y} \\
(t / c m 2)\end{array}$ & $\begin{array}{c}\mathbf{t}_{\mathrm{st}} \\
(\mathbf{m m})\end{array}$ & $\begin{array}{c}\mathbf{b} \\
(\mathrm{cm})\end{array}$ & $\begin{array}{c}\mathbf{h} \\
(\mathrm{cm})\end{array}$ & & $\mathrm{Q}_{1}$ & $\mathrm{Q}_{2}$ & $\mathrm{Q}_{\mathrm{n}}$ & & \\
\hline Po.1 & 23 & 2.4 & 3 & 6.5 & 5 & 4.21 & 4.298 & 7.02 & 4.298 & Concrete crushing & 1.02 \\
\hline Po.2 & 40 & 2.4 & 3 & 6.5 & 5 & 5.1575 & 5.265 & 7.02 & 5.265 & Concrete crushing & 1.02 \\
\hline Po.3 & 60 & 2.4 & 3 & 6.5 & 5 & 6.78 & 6.403 & 7.02 & 6.403 & Concrete crushing & 0.944 \\
\hline Po.4 & 23 & 3.6 & 3 & 6.5 & 5 & 4.6375 & 4.298 & 10.14 & 4.298 & Concrete crushing & 0.926 \\
\hline Po.5 & 23 & 2.4 & 4 & 6.5 & 5 & 5.5775 & 4.734 & 7.02 & 4.734 & Concrete crushing & 0.8487 \\
\hline Po.6 & 23 & 2.4 & 3 & 6.5 & 3 & 3.69 & 3.774 & 7.02 & 3.774 & Concrete crushing & 1.022 \\
\hline Po.7 & 23 & 2.4 & 3 & 2 & 5 & 2.255 & 3.512 & 2.16 & 2.16 & $\begin{array}{l}\text { connector shearing } \\
\text { off }\end{array}$ & 0.957 \\
\hline PO.8 & 23 & 2.8 & 3 & 6.5 & 5 & 4.28 & 4.298 & 8.58 & 4.298 & Concrete crushing & 1.0209 \\
\hline PO.9 & 50 & 2.4 & 3 & 6.5 & 5 & 6.403 & 5.834 & 7.02 & 5.834 & Concrete crushing & 0.9111 \\
\hline PO.10 & 23 & 2.4 & 3 & 6.5 & 6 & 4.689 & 4.559 & 7.02 & 4.559 & Concrete crushing & 0.9722 \\
\hline PO.11 & 23 & 2.4 & 6 & 6.5 & 5 & 5.945 & 5.607 & 14.04 & 5.607 & Concrete crushing & 0.9431 \\
\hline & & & & & & & & & & Mean & 0.962273 \\
\hline & & & & & & & & & & Standard deviation & 0.055974 \\
\hline
\end{tabular}

Where, $\mathrm{Q}_{\mathrm{FE}} / \mathrm{connector}=\mathrm{P}_{\mathrm{FE}} / 4$ (because of the presence of two shear connector in the two sides of the steel beam). 


\section{COMPARISON BETWEEN EXPERIMENTAL AND} THEORETICAL RESULTS AND THE DERIVED EQUATION:

Comparison between the test results and the calculated results from the FEM and the shear resistance calculated from the proposed formula are presented Fig (19), it is noticed a good agreement and. It is noticed that the equation gives good results can be used for the design.

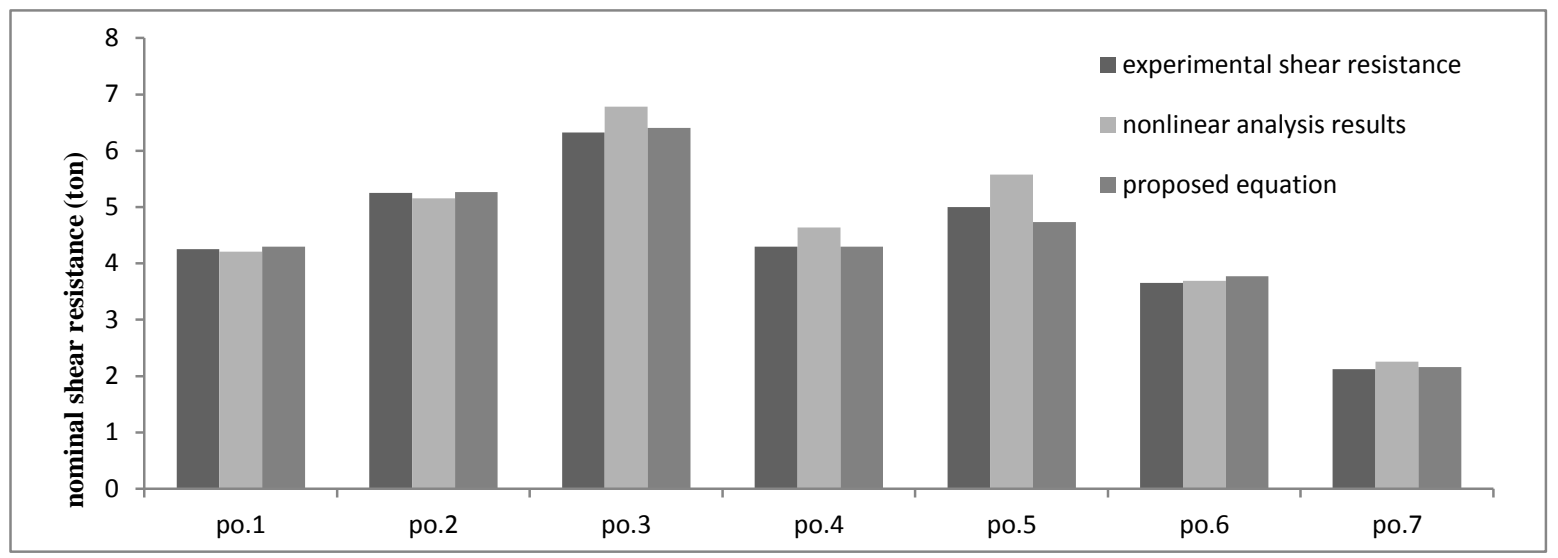

Fig.19.Experimental results versus nonlinear analysis versus the shear resistance calculated from the proposed equation

\section{CONCLUSION}

The following conclusions can be drawn based on the study results:

a. The design shear resistance of the proposed shear connector could be calculated as follow:

$$
\begin{aligned}
& Q_{d}(\text { ton })=\Phi_{s c} Q_{n} \\
& Q_{n}(\text { ton })=\min \text { of }\left(Q_{1} \text { and } Q_{2}\right) \\
& \mathrm{Q}_{1}(\text { ton })=3.7938 f_{c u} t_{s t} h+2.9893 \\
& \mathrm{Q}_{2}(\text { ton })=A_{s c} f_{u}=t_{s t} b f_{u}
\end{aligned}
$$

b. A good agreement has been obtained between experimental results and finite element results that we can perform a lot of push out tests with different varieties for extensive study which will be more economic than the experimental work

c. The failure of the shear connection has two possibilities, the first is the failure or the crushing of the concrete, and the second is the shearing off the steel connector.

d. Increasing the concrete strength increases the shearing capacity of the proposed shear connector.

e. The resistance of the shear connector increases with the increasing of the steel thickness.

f. The yield stress of the steel used in the shear connector has a significant effect on the resistance of the shear connector.

g. Increasing the embedded length of the shear connector inside the concrete increases its resistance

\section{SYMBOLS}

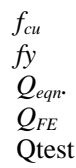

compressive strength of concrete cube yield strength of the used steel

Resistance of the shear connector from the proposed equation Resistance of the shear connector from the finite element Resistance of the shear connector from the experiment

$\begin{array}{ll}b & \text { Breadth of the shear connector } \\ h & \text { Height of the shear connector } \\ t_{s t} & \text { Thickness of the used steel } \\ E c & \text { Young's modulus of the concrete } \\ v & \text { Poisson's ratio } \\ G_{F} & \text { fracture energy } \\ d_{\max } & \text { Maximum coarse aggregate size }\end{array}$

\section{REFERENCES}

[1] Viest, I. M. 1956. Test of Stud Shear Connectors Parts I, II, III and IV, Engrg. Test Data, Nelson Stud Welding, Lorain, Ohio, 1956.

[2] Slutter, R. G., Driscoll, G. C. 1965. Flexural Strength of Steel-Concrete Composite Beams. In: Journal of the Structural Division, ASCE, Vol. 91, No. 2, April 1965. p. 71-99.

[3] Driscoll, G. G., Slutter, R. G. 1961. Research on Composite Design. In: Lehigh University Proceedings, National Engineering Conference, AISC, and May, 1961.

[4] Goble, G. G. 1968. Shear Strength of Thin Flange Composite Specimens. In: Engineering Journal, AISC, Vol.5, No.2, 1968. p. 62-65.

[5] Lam, D., El-Lobody, E. 2005. Behavior of Headed Stud Shear Connectors in Composite Beam. In: Journal of Structural Engineering,ASCE, January 2005. p. 96-107.

[6] British Standards Institution. Code of practice for design of simple and continuous composite beams. BS5950, Part 3: Section 3.1 Structural use of steelwork in building. London; 1990.

[7] CEN.Eurocode 4: Design of composite steel and concrete structures. Part 1: General rules and rules for building. Brussels: CEN; 2006.

[8] American Institute of Steel Construction. Load and resistance factor design specification for structural steel building. Chicago; 1999.

[9] ABAQUS. ABAQUS standard user's manual, version 6.10 . DassaultSystèmes Corp.: Providence, RI (USA);2010

[10] Euro code part 2: Design of the concrete structures;1992

[11] Euro code part 3: Design of the steel structures ; 1993

[12] ECP 2007:" Egyptian Code of practice for steel construction (Load and Resistance Factor design)", code No.205, cairo, Egypt,2007

[13] ELGendy et Al., 2016:" evaluation of shear resistance of Y-shaped ordinary and perfobond shear connector", Tanta, Egypt, 2016.

[14] Dabaon M.A. et al.," Experimental Shear Resistance Evaluation of ordinary and perfobond Y-shaped shear connector", ICASGE, 2015 